\title{
ClassificATION OF THE MODELS AND THE MATHEMATICAL MODELS
}

\author{
Hrubina, K.; Wessely, E.; MAcurova, A. \& BAlcaK, S.
}

Abstract: Mathematical model usually failures if there is a lack in information about contrtolled process. In such a case the procedures of the new scientific branch could be applied, i.e. those of the artificial intelligence whose methods is solution of the problems with constraints. The modelling is a process where other system called model is atteched to the searched system, the object, the original according to the certain criterions.

Key words: Classification of the models, mathematical models, differential equations
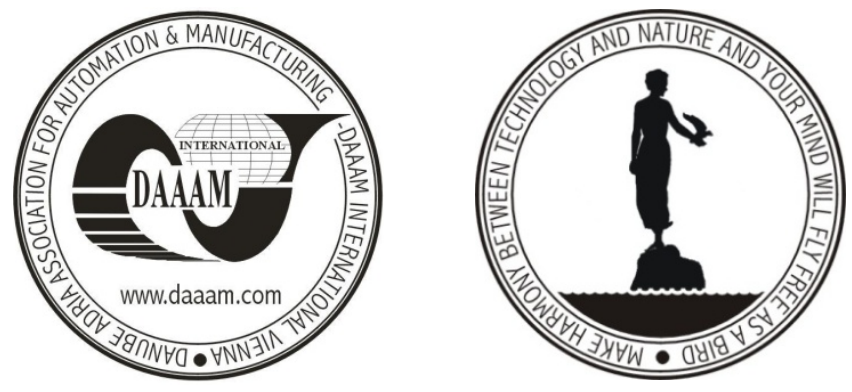

Authors' data: Ass. Prof. PhD. Hrubina, K[amil]; Ass. Prof. PhD. Wessely, E[mil]; Dr. PhD. Macurova, A[nna]; Eng. Balcak, S[tanislav], Technical University of Kosice,Faculty Manufacturing with the Seat in Presov, Department of Mathematics,Informatics and Cybenetics, Bayerova 1, 080 01, Presov, SK, kamil.hrubina@tuke.sk,_ewe.@stonline.sk, anna.macurova@tuke.sk, stanislav.balcak@gmail.com

This Publication has to be referred as: Hrubina, K[amil]; Wessely, E[mil]; Macurova, A[nna] \& Balcak, S[tanislav] (2008). Classification of the Models and the Mathematical Models, Chapter 29 in DAAAM International Scientific Book 2008, pp. 333-348, B. Katalinic (Ed.), Published by DAAAM International, ISBN 978-3901509-66-7, ISSN 1726-9687, Vienna, Austria

DOI: $10.2507 /$ daaam.scibook.2008.29 